\title{
Perception of Awareness on Attractive Appearance Through Industrial Work Practices as an Indicator of Employability Skills
}

\author{
Oot Khotijah \\ Universitas Ahmad Dahlan, Indonesia \\ Email: ootkhotijah@gmail.com
}

\begin{tabular}{|c|c|}
\hline ARTICLE INFO & ABSTRACT \\
\hline $\begin{array}{l}\text { Date received : } 03 \text { January } 2021 \\
\text { Revision date : } 02 \text { February } 2021 \\
\text { Date received : } 01 \text { March } 2021\end{array}$ & \multirow[b]{2}{*}{$\begin{array}{l}\text { he research objective was to analyze the perceptions of } \\
\text { students, teachers, and business advisers about the } \\
\text { awareness of appearing attractive as an indicator of } \\
\text { employability skills in the marketing profession. The study } \\
\text { population was students of SMK Negeri in Cilacap Regency, } \\
\text { Online Business and Marketing Competence. The sample is } \\
\text { determined proportionally by the class rank of } 20 \text { students. } \\
\text { Data collection was carried out by means of observation, } \\
\text { interviews and documentation. Meanwhile, data analysis } \\
\text { was carried out using thematic analysis with the aim of } \\
\text { identifying patterns of themes. The thematic analysis stage } \\
\text { includes: (1) familiarizing oneself with the data; (2) } \\
\text { generate the initial code; (3) search for themes; ( } 4 \text { ) review } \\
\text { the theme; (5) define and name themes; and (6) producing } \\
\text { reports.The results of the study: (1) perceptions of } \\
\text { students, teachers and business advisers about the } \\
\text { awareness of performing attractive contributions to } \\
\text { employability skills; (2) the continuity of topics and themes } \\
\text { that are built on the awareness of appearing attractive } \\
\text { contributes to employability skills in the marketing } \\
\text { profession, (3) differences in perceptions of the three } \\
\text { respondents lead to the role of respondents regarding the } \\
\text { relationship between awareness to appear attractive still } \\
\text { with the character building of employability skills in the } \\
\text { marketing profession. ( } 4 \text { ) the relationship between the } \\
\text { employability skills that appears in the form of perceptions } \\
\text { which refers to the characteristics of the characteristics of } \\
\text { awareness that appear attractive to the marketing } \\
\text { profession. }\end{array}$} \\
\hline $\begin{array}{l}\text { Keywords: } \\
\text { Awareness to appear attractive } \\
\text { Eemployability skills } \\
\text { Teachers } \\
\text { Business advisers } \\
\text { Vocational high school students }\end{array}$ & \\
\hline
\end{tabular}

\begin{tabular}{ll} 
How to cite: & $\begin{array}{l}\text { Khotijah, Oot (2021) Perception of Awareness on Attractive Appearance Through } \\
\text { Industrial Work Practices as an Indicator of Employability Skills, 2(3). } \\
\text { https://doi.org/10.46799/jsss.V2i3.115 }\end{array}$ \\
\hline E-ISSN: & $2721-5202$ \\
\hline Published by: & Ridwan Institute \\
\hline
\end{tabular}




\section{INTRODUCTION}

Fulfillment of human resources who have qualified competencies can be obtained through Vocational High Schools (SMK). SMK is expected to be able to support the acceleration of national development. Vocational and curriculum adjustments are needed so that there is relevance between vocational high school education and the field of work. In the era of the Industrial Revolution 4.0, education actors must adapt to various existing developments.

Facts on the ground show that most unemployment is dominated by secondary education graduates. The Central Statistics Agency states that the Open Unemployment Rate in February 2018 with the highest position, namely 8.92 percent, reaching 6.87 million people is occupied by vocational graduates (Catalog: 9199017). This is due to the lack of readiness of Vocational High Schools graduates to enter the world of work and also the competence of SMK graduates who are still far from the estimated needs of the world of work (Pertiwi \& Indrawati, 2019). The level of mastery of student competencies is still low, this is reflected in the ineffective and optimal learning approach implemented in schools and vocational graduates (Amalia \& Suwatno, 2016).

The problem of job readiness awareness is a significant problem in the world of SMK. Graduates who do not prepare themselves for the world of work will become unemployed because they are unable to compete. The right step in overcoming the increasing unemployment rate is carried out by identifying the employee's figure to be able to influence customer performance and behavior needed in the world of work (Shtudiner, 2019). Along with the development of technology and free trade, the world organizations UNESCO and the ILO provide an overview of general skills, namely: being able to adapt, knowing how to learn, being able to organize and process existing information to solve problems independently, lifelong learning, able to read, write and count well, listen and communicate effectively, think creatively, interact with colleagues, work in groups, master basic technology, can lead and follow directions effectively (Brewer, 2013).

At the University of Tunisia, 54 indepth interviews were conducted with results showing that personal branding is a multidimensional construction involving six dimensions, namely cultural capital, social capital, verbal self-presentation, mediated self-presentation, authenticity, and appearance. These elements add value to graduates and shape their work outcomes (Khedher, 2019). The ability to communicate and adapt teachers and students through appropriate learning methods will make it easier for teachers to instill aspects of employability skills.

Employability skills are very important to train students to shape students' attitudes in working on practical activities and how they apply them someday in the world of work. Motivating to build attractive character is the application of learning to excite student learning in the process of learning activities that are fun and not boring and are expected to increase student interest in these lessons so that they can increase student learning motivation themselves.

(Susanti, Waras, \& Dardiri, 2015) research on the contribution of student perceptions of teacher quality, suitability, and industrial work practice results to employability skills concluded that students' perceptions of teacher quality, suitability of industrial work practices and results of industrial work practices have an effect and contribute to employability student skills either partially or simultaneously. The suitability of industrial work practices makes a big contribution because industrial work practices will shape students' mentality as a work-ready workforce and provide the right experience for students in recognizing the work environment and work that students will do when working according to their competency skills. The results of industrial work practice are the smallest contribution among other variables due to differences in the subject assessing and the attitudes of each student towards the results obtained.

Research on the contribution of industrial work practice experience, worldview work and vocational competence through employability skills and their impact on job readiness of graduates of the Computer and Network Engineering Skills Competency Vocational School in Probolinggo are in good categories (Putriatama, Patmanthara, \& Sugandi, 2016). There is a significant and positive influence between industrial work 
practice experience, insight into the world of work and vocational competence on employability skills.

The difference between this study and previous research is that the awareness factor appears attractive, which in previous studies has not revealed the awareness factor to appear attractive in relation to employability skills.

The effectiveness of inculcating cognitive, attitude and psychomotor values can be developed using appropriate learning methods. The accuracy (effectiveness) of using learning methods depends on the suitability of the learning method with several factors, namely learning objectives, learning materials, teacher abilities, student conditions, resources or facilities, conditions and time (Sumiati, 2009).

The learning process is needed to support the optimal employability skills (Fugate, Kinicki, \& Ashforth, 2004). Work skills as a form of active and job-specific adaptation that enable workers to identify and realize career opportunities and job abilities can be characterized as relative opportunities to obtain and maintain different types of jobs (Brown, 1994). The international definition of job skills goes by many different names. The name varies depending on the country where the term is used. A number of studies suggest that the existence of attractive appearance is an option to be used as relevance in the recruitment of workers who are more ready than workers who do not have attractive abilities (Mobius \& Rosenblat, 2006). The "truth kernel" hypothesis, stereotypical physical attraction may better be predictable because better looking children are expected to outperform their peers and thus be given special treatment in the corporate world, which in turn builds self-confidence as well as social and skills communication (Mobius \& Rosenblat, 2006). Social and communication skills improve to help individuals who appear attractive to be more credible (Patzer, 2012).

This research can be used as one of the important factors besides Information Technology (IT) in convincing SMK graduates as ready-to-use workers in the world of work that what needs to be applied is to have awareness and provide stimulation to appear attractive so that it can increase the ability of employability skills. That is why the problems in vocational students are a serious concern that must be addressed immediately. As a contribution in the era of the Industrial Revolution 4.0 and convincing students that not all jobs will be replaced by IT, but a workforce that has an attractive appearance and maximum service quality is still needed (Li, Zhang, \& Laroche, 2019). Students who have job readiness are students who have the skills, knowledge, understanding and personality that make someone able to choose and feel comfortable with their job so that they become satisfied and ultimately achieve success.

Starting from the description above, the writer intends to conduct research on: "Perceptions of Awareness of Appearing Attractive through Industrial Work Practices as an Indicator of Employability Skills".

\section{METHOD}

The type of research used is qualitative research (Heriyanto, 2018). The technique of analyzing in this research is through thematic analysis (Braun \& Clarke, 2006). The purpose of thematic analysis is to identify themes and patterns namely in important or interesting data, and to use these themes to address research or say something about a problem (Braun \& Clarke, 2006).

The thematic research design used in this study was to collect data from class XI students of the Online Business Skills and Marketing Competency of Vocational High School in Cilacap Regency. The initial data collected includes the opinion of each child about the attractive appearance in this era of globalization. The research was conducted in two classes, namely for each class student who had finished carrying out industrial work practices from planning, implementation to evaluation. Students will see a change in attractive attitudes after students carry out the complete industrial work practice process.

Thematic analysis involves vocational school students, teachers and business advisers regarding awareness of appearing attractive as an indicator of employability skills in the marketing profession. Code grouping according to the similarity of meaning in this study includes:

1. Perception according to students

2. Perception according to the teacher

3. Perception according to the bussines advisers 
Validity is the degree of accuracy between data that occurs on the object of research and data that can be reported by researchers. Thus, valid data is data that does not differ between the data reported by the researcher and the data that actually occurs on the research object.

Guidelines in conducting thematic data analysis (Braun \& Clarke, 2006) through several stages: 1 . Familiarizing yourself with the data, 2. Generating the initial code, 3. Look for a theme, 4. Reviewing the theme, 5. Defining and naming the theme, 6 . Producing reports.

Thematic analysis of data is carried out by organizing data, describing it into units, synthesizing, arranging into patterns, choosing which ones are important and which will be studied and making conclusions that can be shared with others (Agusta, 2003).

\section{RESULTS AND DISCUSSION}

Based on preliminary data about aspects of research, the researcher decided to motivate students to be able to foster awareness of appearing attractive by involving teachers and mentors of the business world.

1. Perceptions of students, teachers, and business advisers about awareness appear attractive.

a. Appearing Attractive According to Students.

In the phenomenon of perception, consciousness appears attractive from students' opinions, a theme is built:

b. Confidence

The opinions expressed by several students revealed that looking attractive can build a person's character to be more confident. Selfconfidence has a positive impact on someone in the world of work. Selfconfidence can affect the continuity of one's career. By having self-confidence, everyone will be able to complete their tasks well and be liked by everyone. In addition, the negative impact caused by a lack of self-confidence is that it can reduce the quality of that person.

\section{c. Professionals}

Professionals in making appear attractive can make someone have a good image in the eyes of others. In working, a professional attitude is needed to make the work done to be the best result. A professional attitude is also an aspect of appearing attractive that can be learned and understood by everyone in order to grow their quality.

\section{d. Provide Traction}

Attraction is the ability to attract attention. Attraction makes a positive impression and makes it easier for someone to invite others. Things that must be improved in shaping yourself to have attractiveness can be started from having an attractive body gesture, dressing neatly, politely and according to company standards. Besides that, the positive impact of having an attraction is that it can provide satisfaction to others with something that has been done. Having good personal characteristics can give a positive impression in doing work. With positive personal characteristics can give someone interest in someone to give an invitation or offer something.

\section{e. Positive Impressions}

Neat, polite appearance in accordance with company operational standards can give a positive impression to the viewer. By giving an attractive impression one can easily shape the mindset of others in a positive way. Vocational high school students in marketing competencies have been able to contribute to industrial work practices. Contribution of industrial work practice experience and students' perceptions of the awareness of appearing attractive by students starts from participating in planning, implementation and evaluation.

\section{Appearing Attractive According to Teacher}

In the phenomenon of the perception of consciousness appearing attractive from the teacher's opinion the theme is built:

a. Establish good communication to work together

Communication is needed to be able to convey thoughts and reach a consensus in a discussion. In a team to be able to build good cooperation, one of the most appropriate ways is to 
improve the quality of communication between its members. Of course, good communication is the key to the success that the team can achieve. Communicating effectively and well will also make the relationship of each team member closer and support each other. By appearing attractive, you can give the impression that you can establish good communication with others, making it easier for someone to have good cooperation. Each teacher will give positive things to each student to form the character of students who have high quality.

b. Has Good Performance

Performance is a condition that must be known and confirmed to certain parties to determine the level of achievement of an agency's results related to the vision carried by an organization or company and to know the positive and negative impacts of an operational policy. Basically, performance appraisal is a key factor in developing an organization effectively and efficiently, because of the existence of a better policy or program for human resources in the organization. Individual performance appraisal is very useful for the dynamics of organizational growth as a whole, through this assessment it can be seen the actual conditions of how employees are performing. By teaching students to appear attractive each teacher also directs students to have good performance in facing the world of work. The teacher will guide through practice and convey theory to students as a provision for students to face the world of work.

c. Ready to Face the World of Work

The world of work is an environment related to the work we are in, from this definition we know that we are aimed at jobs that we like and are good at. For teachers as student teaching staff who have an attractive appearance, it shows that these students have mastered and applied the skills or abilities needed in the world of work. In the teaching and learning process, it will create a conducive, active and fun learning atmosphere which results in a planned teaching and learning process that has been made easy to apply and apply.

\section{Appearing Attractive Accordig to the Business Advisers}

In the phenomenon of the perception of consciousness appearing attractive from the business world, the theme is built:

a. In accordance with Company Operating Standards

In general, Standard Operating Procedures on the duties and functions of each element in the company. The existence of Standard Operating Procedures is also a guide for running and facilitating, order and tidy up existing work. Standard Operating Procedures must be followed by all employees to perform work. In doing work in a company must be in accordance with the company regulations that have been determined. That way the company can easily control a large number of employees. The company's goal is to get the maximum benefit from each employee's performance.

b. Professional Atitude

A professional attitude must be possessed by every employee who carries out his job in accordance with their expertise or abilities. An employee who has a professional attitude can position himself so that he is able to understand his duties and responsibilities, relationships and relationships, as well as focus and be consistent with his work affairs. A professional attitude is important in the world of work because it will have a positive impact on the company. Professionalism in work is considered one of the most important aspects to achieve success at work. Having a responsibility in working to get the maximum results that is desired by every company. Appearance is the main thing to form a person's image in the world of work. By having an appearance that is in accordance with Standard Operating Procedures, it will be able to form a professional image at work.

c. Education about Performance 
Performance is the result or overall success rate of a person during a certain period in carrying out a task compared to various possibilities, such as work standards, targets or targets or criteria that have been predetermined and agreed upon. Having good performance will make the company have an advantage. the big one. Therefore, every company provides work standards for each employee in order to have good performance.

4. The topics of awareness appear attractive according to the character of the employability skills of the marketing profession.

From the three respondents about the attractive appearance obtained the topics of indicators that appear for the character of students in preparing to enter the world of work as follows: critical thinking, communicate effectively, have strength, the spirit of study and work, initiative and flexibility.

\section{Critical Thinking}

Critical thinking at work is needed to provide satisfaction at work. Every company requires employees to have good performance, just as the marketing profession requires critical and careful thinking to provide maximum service to every customer.

2. Communicate Effectively

Communication is something that needs to be given more attention at work. With effective communication, all work will be completed properly. To improve communication in order to be effective, namely by having an attractive appearance so that you can interact perfectly with consumers.

3. Have Strength

By having a good performance every employee must have a responsibility to each job. That way employees will have the strength to continue to improve the quality of their work. By having the power at work everyone will not be easily replaced by technology. Many efforts must be made to improve the quality of oneself so that everyone is not easily replaced by increasingly rapid technology. The way that can be done is by continuing to improve his quality.
4. The spirit of study and work

In any environment it can be contagious, be it ignorance, intelligence, laziness, ugliness, kindness, and of course the intention and enthusiasm in studying / working. If we are in an environment that has the same goals it can be very motivating for us. So try to find an environment / friend with the same goals and goals to motivate each other. Having a sense of enthusiasm in learning will foster high initiative in doing work. Not only that, a sense of enthusiasm for learning has a positive value for everyone to do a job.

5. Initiative

Initiative is a person's ability to produce something new to solve a problem. People who have the initiative can immediately see the problems that arise and find solutions to these problems. Usually the solution can be done quickly so that the problem can be resolved immediately. By having the initiative, someone will easily find solutions to solve their problems, both personal problems and problems at work. Especially in doing employee work, it is necessary to have many initiatives to provide satisfaction to customers. That way, it can provide creative ideas in work as conveyed by one of the business advisers.

6. Flexibility

Flexibility or the ability to adapt and work effectively in different situations with various individuals or groups. Flexibility is one of the positive things about working with enthusiasm. In the world of work students will be trained to be responsible for their work. At school students will be guided to take part in learning to prepare themselves for the world of work. The attitude that must be cultivated by students is the enthusiasm for learning and practicing in order to have high quality at work.

5. Similarities and differences in views of consciousness appear attractive

From the three opinions about appearing attractive above, it can be concluded that the similarities and differences in the views of each element. 
The opinions expressed by each element have their own character. Each element has its own view of the awareness to appear attractive. The importance of this research is to balance the ability of Information Technology (IT) and to convince SMK graduates who are readyto-use workers in the world of work who must be applied in order to have awareness and provide attractive appearances that can increase employability skills. That is why the problems in vocational students are a serious concern that must be addressed immediately. As a contribution in the era of 4.0 and convincing students that not all jobs will be replaced by IT, but it is still necessary to have a workforce who has an attractive appearance and maximum work readiness. Students who have job readiness are students who have the skills, knowledge, understanding and personality that make someone able to choose and feel comfortable with their job so that they become satisfied and ultimately achieve success.

The common view of consciousness appears attractive in the marketing profession such as the character building of readiness to work between students, teachers and the business world is almost the same, that is, not only IT skills are highlighted, but also other supporting aspects, including self-confidence, professionalism, attraction and positive impression The similarities of the three elements that have been disclosed by the respondents are Student work readiness, shaping student character, the urgency to appear attractive, creating quality human resources.

Work readiness in the face of work challenges. Work readiness in question is the preparation of students in facing physical challenges, including the readiness to establish good communication for cooperation in speaking, to appear confidently, professionally, to provide attractiveness and a positive impression.

Shaping the character of each student to be more confident, professional, and able to give positive things. The same is the case with the teacher's opinion that has been conveyed that appearing attractive is a capital to practice for students in facing the world of work. Not only that, the opinions of several business worlds also reveal that looking attractive can provide benefits for the company because the company gets employees who have high performance. This is evidence that the opinions of the three elements that have been conveyed have the same desire to create highperformance HR.

Have the same view that looking attractive is important in all aspects, especially in the world of work. Of the three elements above give the same opinion in terms of conveying the importance of understanding and applying to appear attractive in all aspects of life to increase and facilitate all activities.

We both want to create high quality human resources. From several students' opinions, it is revealed that appearing attractive is important to shape the character of each person so that they become more confident, professional, and can give positive things. The same is the case with the teacher's opinion that has been conveyed that appearing attractive is a capital to practice for students in facing the world of work. Not only that, the opinions of several business worlds also reveal that looking attractive can provide benefits for the company because the company gets employees who have high performance. This is evidence that the opinions of the three elements that have been conveyed have the same desire to create high-performance HR.

Different views of consciousness appear attractive in the marketing profession such as work readiness mindset, the perspective on the role appears attractive, the different objectives of each role.

The mindset between students, teachers and mentors in the business world has a difference, namely where students feel that they have been equipped with the learning that has been given at school, even though according to teachers and the business world students must develop what has been provided in school, for example at school they provided with debriefing materials for work, students are not fixated on the 
material but rather explore the material in the real world.

Each of each element provides a view about appearing attractive, referring to their respective roles. Each element provides views and opinions on their respective roles as actors. This can be seen and proven in the results of interviews conducted by researchers. For example, students give an opinion that appears attractive and has a confident aspect in it because students already have experience during industrial work practices. Likewise with elements that have their respective roles.

Opinions of each element serve different purposes. The opinions expressed by each element have their own different goals. With this opinion, each element has a different purpose according to its role. For example, a teacher gives an opinion that appears attractive is an appearance that has a ready aspect in facing the world of work. This has the aim of providing readiness to every student in facing the world of work. It's the same with other elements.

6. Lingkage of Awareness to Appear Attractive with Employability Skilla Employability skills means a set of abilities that each graduate must have to support his main competencies.

Mastery of Vocational School students in the field of Online Business and Marketing expertise over the qualifications that are requested and needed by the business world has been prepared. Vocational high school students in any major are prepared to become a reliable workforce.

In this study, it can be proven that forming employability skills in online business and marketing students begins with the awareness of each student towards attractive appearances made during industrial work practices. That appearing attractive is not only physical appearance but also the overall character of the aspects of the employability skills possessed by each student. The link between appearing attractive and employability skills makes students need to understand both. Research that has been carried out with this thematic analysis method is different from previous research stated by (Myron et al., 2018) which states that being attractive is more associated with physical and sexual attractiveness, with findings showing that the assessment of attractiveness requires awareness, further assessment reveals that Correct detection of faces is presented at a more attractive ranking condition for faces.

Previous research said that appearing attractive is more about physical appearance. However, this research states that appearing attractive leads to the characteristics of the characteristics that are needed by the business world in fulfilling the workforce. This study reveals that appearing attractive includes several aspects in students to help shape the character of students who are ready to face the world of work. In the research that has been conducted, the researcher revealed that students' employability skills can be formed by means of students having the awareness to appear attractive. The relationship between the two forms the character of Online Business and Marketing students to be ready to face the world of work with the provision of theoretical and practical learning in shaping students' employability skills to be ready to work. The results of this study can be seen from Figure 1.

\section{CONCLUSION}

Based on the results of the research and discussion that has been described, it is concluded that there are various perceptions that have been conveyed by students, teachers and business advisers as respondents about the awareness of appearing attractive. Through the perceptions conveyed by the three respondents, conclusions can be drawn about the awareness of appearing attractive in the marketing profession in relation to students' employability skills. In industrial work practice activities, students are given sufficient provisions to have employability skills at work. Industrial work practice activities that have been carried out by students can be used as evidence that the awareness of appearing attractive is important to support students' readiness to face the world of work. 
The topics of awareness appear attractive in accordance with the character of employability skills in the marketing profession, including 1) critical thinking, 2) communicating effectively, 3) having strength, 4) enthusiasm for learning and work, 5) initiative and 6) flexibility.

Each of the perceptions conveyed by the three respondents had the same goal, namely to build awareness of appearing attractive and prove a link with the employability skills of Vocational High School students. In addition, the results of interviews conducted by researchers to the three respondents proved that there was a link between being attractive and employability skills for the marketing profession. The awareness of appearing attractive which can be formed by each student is a provision to form the character of students who are ready to work.

Further researchers are expected to develop this research because by increasing the number of more in-depth studies about independent practice regarding the awareness of appearing attractive, especially those related to employability skills in the marketing profession can motivate vocational students so that student concerns will be minimized with a lot of research to convince Online Business and Marketing Competence students will not being eliminated by having a strong and positive character, one of which is by realizing that looking attractive is proof of readiness in facing the business world.

\section{REFERENCES}

Agusta, Ivanovich. (2003). Teknik Pengumpulan dan Analisis Data Kualitatif. Pusat Penelitian Sosial Ekonomi. Litbang Pertanian, Bogor, 27. Google Scholar

Amalia, Lia, \& Suwatno, Suwatno. (2016). Peningkatan kompetensi siswa melalui efektivitas competency based training. Jurnal Pendidikan Manajemen Perkantoran (JPManper), 1(1), 30-37. Google Scholar

Braun, Virginia, \& Clarke, Victoria. (2006). Using thematic analysis in psychology. Qualitative Research in Psychology, 3(2), 77-101. Google Scholar
Brewer, Laura. (2013). Enhancing youth employability: What? Why? and How? Guide to core work skills. ILO. Google Scholar

Brown, Kate M. (1994). Using role play to integrate ethics into the business curriculum a financial management example. Journal of Business Ethics, 13(2), 105-110. Google Scholar

Fugate, Mel, Kinicki, Angelo J., \& Ashforth, Blake E. (2004). Employability: A psycho-social construct, its dimensions, and applications. Journal of Vocational Behavior, 65(1), 14-38. Google Scholar

Heriyanto, Heriyanto. (2018). Thematic Analysis sebagai Metode Menganalisa Data untuk Penelitian Kualitatif. Anuva: Jurnal Kajian Budaya, Perpustakaan, Dan Informasi, 2(3), 317-324. Google Scholar

Khedher, Manel. (2019). Conceptualizing and researching personal branding effects on the employability. Journal of Brand Management, 26(2), 99-109. Google Scholar

Li, Yaoqi, Zhang, Chun, \& Laroche, Michel. (2019). Is beauty a premium? A study of the physical attractiveness effect in service encounters. Journal of Retailing and Consumer Services, 50, 215-225. Google Scholar

Mobius, Markus M., \& Rosenblat, Tanya S. (2006). Why beauty matters. American Economic Review, 96(1), 222-235. Google Scholar

Myron, Rowan, French, Catherine, Sullivan, Paul, Sathyamoorthy, Ganesh, Barlow, James, \& Pomeroy, Linda. (2018). Professionals learning together with patients: An exploratory study of a collaborative learning Fellowship programme for healthcare improvement. Journal of Interprofessional Care, 32(3), 257-265. Google Scholar

Patzer, Gordon L. (2012). The physical attractiveness phenomena. Springer Science \& Business Media. Google 
Scholar

Pertiwi, Ni Putu Angelina Nanda Devi, \& Indrawati, Komang Rahayu. (2019). Peran kecerdasan sosial dan orientasi masa depan terhadap kesiapan kerja siswa SMK di Bali. Jurnal Psikologi Udayana, 123-133. Google Scholar

Putriatama, Ega, Patmanthara, Syaad, \& Sugandi, R. M. (2016). Kontribusi pengalaman prakerin, wawasan dunia kerja dan kompetensi kejuruan melalui employability skill serta dampaknya terhadap kesiapan kerja lulusan SMK kompetensi keahlian teknik komputer dan jaringan di Probolinggo. Jurnal Pendidikan: Teori, Penelitian, Dan Pengembangan, 1(8), 1544-1554. Google Scholar

Shtudiner, Zeev. (2019). The Impact of
Attractiveness on Retail Managers' Decisions: Labor Market Discrimination When Hiring Salespeople. Modern Economy, 10(11), 2253. Google Scholar

Sumiati, Asra. (2009). Metode pembelajaran. Bandung: Wacana Prima. Google Scholar

Susanti, Aria Indah, Waras, Waras, \& Dardiri, Ahmad. (2015). Kontribusi persepsi siswa tentang kualitas guru, kesesuaian, dan hasil prakerin terhadap employability skills siswa SMK. Teknologi Dan Kejuruan: Jurnal Teknologi, Kejuruan Dan Pengajarannya, 38(2). Google Scholar

\section{Copyright holder: \\ Oot Khotijah (2021)}

First publication right:

Journal of Social Science (JSS)

This article is licensed under: 